\title{
Absensi Pengenalan Wajah Menggunakan Menggunakan Algoritma Eigenface Berbasis Web
}

\author{
Satria Putra ${ }^{1 *}$, Iskandar Fitri ${ }^{2}$, Sari Ningsih ${ }^{3 *}$ \\ * Program Studi Teknik Informatika, Universitas Nasional \\ $\underline{\text { satriacening@gmail.com }}{ }^{1}$, tektel2001@yahoo.com ${ }^{2}$, sariningsih.lectures@ yahoo.com $^{3}$
}

\begin{tabular}{l} 
Article Info \\
\hline Article history: \\
Received 2020-12-05 \\
Revised 2021-02-04 \\
Accepted 2021-02-07 \\
\hline
\end{tabular}

Keyword:

Eigenface,

Face recognition,

Attendance.

\begin{abstract}
During the Covid-19 virus pandemic as it is currently being experienced in Indonesia is very rapidly spreading, forcing the government to impose a PSBB (Pembatasan Sosial Bersekala Besar) system in several regions in Indonesia. With the government regulation on health protocols, many companies must take action to minimize the spread of the Covid-19 virus. In this situation with daily activities opens opportunities for the Covid-19 virus to spread very quickly, especially in the office sphere. The spread of the Covid-19 virus could be through an attendance system that still uses finger print tools used to collect employee attendance data. In this study, attendance application developed using facial recognition method as key for employee data retrieval. This method of facial recognition is applied in real time with a certain distance and lighting. Eigenface algorithm is used as a training process for employees' faces that have been inputted before. The results of the training data will be saved to a database which is then used as a key to recognize the faces of employees who will perform attendance. In the results of the trial the attendance data application will enter when the level of facial recognition is above $70 \%$.
\end{abstract}

This is an open access article under the CC-BY-SA license.

\section{Pendahuluan}

Absensi adalah sebuah aktivitas pengambilan data yang bertujuan untuk mengetahui jumlah kehadiran pada anggota atau karyawan. Penggunaan absensi ini sering digunakan pada sebuah instansi atau perusahaan yang mempunyai banyak anggota. Fungsi utama dari absensi yaitu menghitung jumlah kehadiran anggota untuk mengetahui berapa upah yang harus di berikan pada anggota [1]. Dengan implementasi sistem aplikasi absensi yang baik diharapkan dapat membantu menyelesaikan pekerjaan input data karyawan dengan lebih mudah dan sesuai dengan apa yang diharapkan [2]. Pemanfaatan aplikasi web dan mobile bisa menjadi solusi yang tepat dan praktis dikarenakan kemudahan akses data serta pengambilan informasi.

Seiring berjalannya waktu sistem absensi kian berkembang. Berbagai jenis sistem absensi pula telah berkembang seperti dengan menggunakan metode barcode dan sidik jari [3]. Permasalahan pada sistem absensi barcode muncul ketika anggota karyawan tidak membawa kartu yang atau alat lainnya yang telah diberi barcode, maka karyawan tidak akan bisa melakukan absensi. Dimasa pandemi covid-
19 penggunaan sistem absensi sidik jari tidak bisa gunakan. Kelemahan alat pemindai sidik jari yaitu satu alat yang digunakan secara bersamaan oleh semua karyawan yang memungkinkan virus covid-19 menyebar melalui alat tersebut. Maka dari itu metode pengumpulan data absensi karyawan harus dirubah. Dengan aplikasi absensi online berbasis web absensi menggunakan metode pengenalan wajah karyawan dapat menggunakan wajah sebagai sebagai id untuk melakukan absensi. Para karyawan bisa mengakses aplikasi tersebut melalui pc/laptop dan smart phone masingmasing sehingga terhindar dari kontak dengan karyawan yang lain.

Perkembangan teknologi inipun sangat berpengaruh dengan cara kerja sistem dalam pengambilan data karyawan sebagai validasi yang bertujuan untuk menggantikan cara kerja sistem yang sebelumnya digunakan. Contoh penerapan teknologi fingerprint dan juga barcode [4]. Teknologi ini dikembangkan karena peluang kesalahan input data sangat kecil dan terhindar dari kecurangan dalam input data.

Metode pengenalan wajah merupakan salah satu teknologi biometrik yang telah banyak digunakan dalam beberapa sistem keamanan selain dari pengenalan retina mata dan 
pengenalan sidik jari. Kekurangan dalam metode sidik jari ketika sidak jari seseorang terluka atau kotor akan menggangu proses scanning pada sensor. Permasalahan utama pada penelitian kali ini metode sidik jari tidak bisa diterapkan selama masa pandemi. Device finger print sensor digunakan secara bersamaan yang berpotensi menjadi media penebaran virus covid-19, sehingga metode pengenalan wajah menjadi solusi terbaik. Cara kerja pengenalan wajah menggunakan sebuah device kamera atau webcam yang bisa diakses secara realtime untuk menangkap sebuah citra wajah dan kemudian dibandingkan dengan id wajah yang telah ditraining sebelumnya [5].

\section{Metode Penelitian}

Metode penelitian yang diadopsi dalam penelitian adalah metode penumpulan data kuantitatif. Metode kuantitatif merupakan sebuah metode yang berdasarkan bukti emprisis dengan tujuan untuk mendapatkan pola atau model matematis, pembuktian teoritis dan dan hipotesis. Berdasarkan pengalaman peneliti yang didapatkan kemudian dikembangkan kembali sehingga didapatkan pokok permasalahan beserta solusi dan pembaharuan.

\section{A Algoritma Eigenface}

Kata eigenface adalah penggabungan antara 2 kata yang berasal dari bahasa Jerman "eigenwert" kata "eigen" memiliki arti karakteristik sedangkan "wert" adalah nilai. Algoritma Eigenface merupakan salah satu algoritma image processing yang mengadopsi konsep Principal Component Analysis (PCA) yang bertujuan mengurangi dimensionalitas serta mencari nilai vektor tertinggi yang kemudian digunakan untuk mendistribusikan citra wajah [5-6]. Nilai eigenvector diurutkan dari eigenvalue tertinggi menuju kenilain paling terendah yang kemudian difilter dari banyaknya nilai eigenvector untuk mendapatkan bentuk pricipal component. Perhitungan Eigenface menggunakan Principan Component Analysis (PCA) adalah sebagai berikut [7-10].

1) Menyiapkan data. Dalam tahap ini citra wajah yang merupakan data training (Ti) harus dipersiapkan terlebih dahulu.

2) Mencari selisih rata-rata. Rata-rata matriks $\boldsymbol{\Psi}$ harus dihitung, kemudian dikurangi dari data training wajah $\left(T_{i}\right)$ dan hasilnya akan di simpan pada variabel $\phi_{i}$

$$
\begin{aligned}
& \psi=\frac{1}{M} \sum_{n-1} T_{n} \\
& \phi_{i}=T_{i}-\psi
\end{aligned}
$$

3) Menghitung matriks kovarian. Langkah selanjutnya adalah menghitung matriks kovarian $\mathrm{C}$ berdasarkan,

$$
C=\frac{1}{M} \sum_{n-1} \phi_{n} \text { कalignc }{ }_{n}^{T}
$$

4) Menghitung eigenvector dan eigenvalues dari matriks kovarian. Dalam tahap ini eigenvectors (eigenface) $\mu_{i}$ dihasilkan dari matrik kovarian $\mathrm{C}$ yang disesesuaikan berdasarkan eigenvalues $\lambda_{i}$.

5) Memilih komponen utama. Dari $M$ eigenvector (eigenface) $\mu_{i}$, hanya $M^{\prime}$ yang dipilih memiliki eigevaluees terbesar. Semakin besar eigenvalues maka semakin besar karakteristik fitur dari citra wajah yang telah digambarkan oleh eigenvectors.

Eigenface pada umumnya adalah himpunan eigenvectors. Eigenvector diturunkan dari nilai matriks kovarian dari ruang vektor yang berasal dari wajah-wajah manusia [12-13]. Demi mendapatkan eigenface sejumlah himpunan gambar citra wajah diambil dalam kondisi pencahayaan yang sama kemudian dapat dilakukan normalisasi.

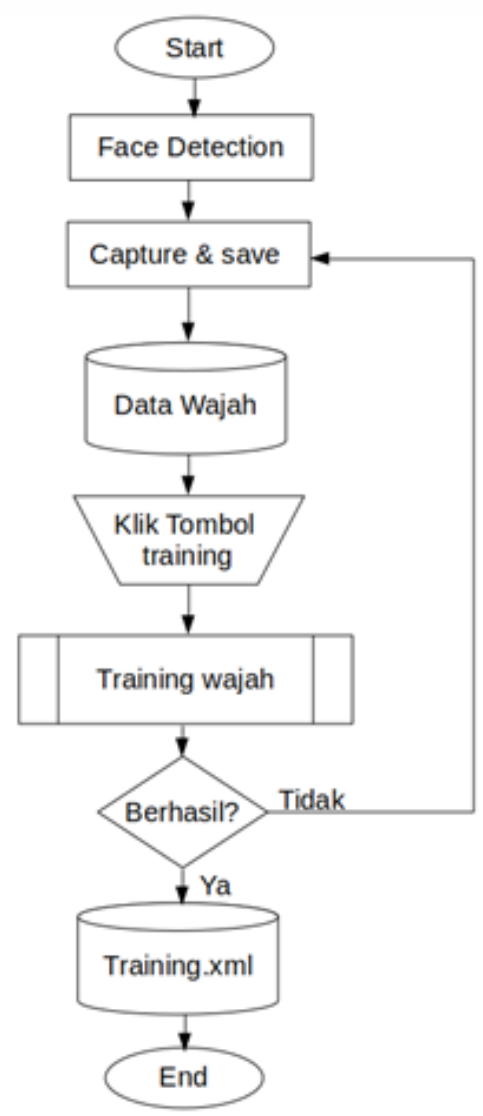

Gambar 1. Diagram alur Training

Pada gambar 1 menunjukan alur proses dalam pengambilan dan training wajah oleh user admin. Gambar wajah telah diambil maka kemudian akan disimpan didalam folder. Ketika user menekan tombol trainig maka program akan menjalankan proses training dengan menggunakan algortima eigenface dari gambar wajah yang telah disimpan. Jika training wajah berhasil maka data training akan disimpan kedalam Training.xml apa bila proses training gagal perlu dilakukan pengambilan ulang gambar wajah. 


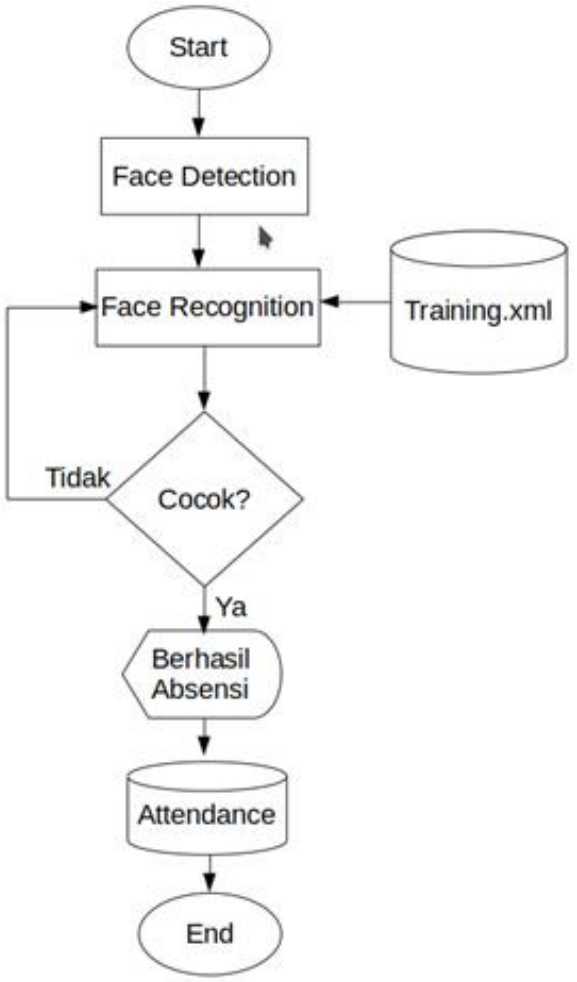

Gambar 2. Diagram alur absensi

Dalam gambar 2 merupakan diagram alur atau tahapan proses absensi. Langkah pertama webcam akan akan mendeteksi wajah yang kemudian akan dicocokan kedalam database training yang sudah disiapkan sebelumnya. Jika citra wajah telah ditemukan di dalam database maka absensi berhasil dan di simpan ke database Attendance MySQL.

\section{B Perancangan Aplikasi}

Aplikasi Absensi ini dibangun menggunakan basis website dengan bahasa pemrograman PHP dan HTML yang ada didalam website. Bahasa PHP digunakan untuk pemrograman koneksi ke database, integrasi antar halaman dan membuat fungsi-fungsi pada aplikasi. Bahasa Pemrograman HTML fungsi pada umumnya adalah untuk menyusun tata letak teks dan seperti headling, paragraf dan tombol pada aplikasi web. Aplikasi absensi yang dibangun dengan 2 level user, yaitu admin dan clien. Fungsi utama user admin ialah input, edit, delete data karyawan dan fungsi admin pada umumnya. Pada level user inilah training data wajah dilakukan yang nantinya digunakan sebagai verifikasi absensi yang dilakukan pada level user client.

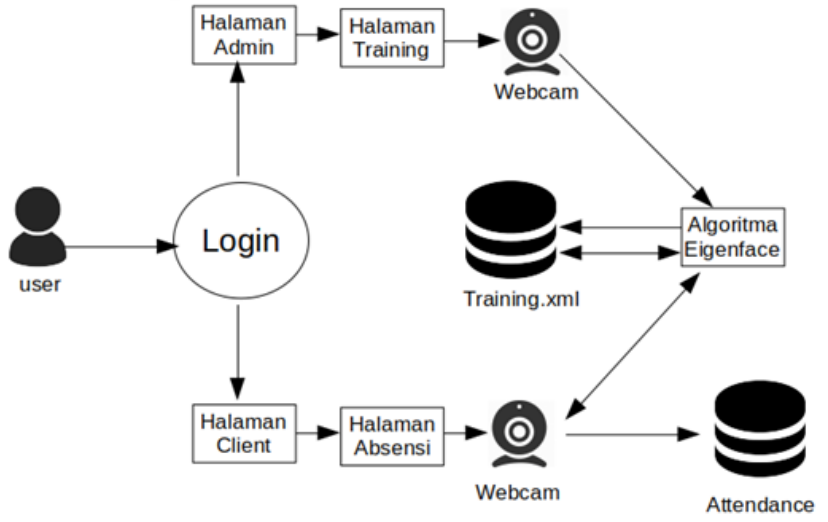

Gambar 3. Struktur Aplikasi

Pada gambar 3 diperlihatkan struktur dari aplikasi yang di buat pada penelitian ini. Ketika user admin login untuk training akan mengambil capture dan di training dengan algoritma eigenface. Hasil training akan disimpan ke dalam file Training.xml yang nantinya akan digunakan ketika user login sebagai client untuk melakukan absensi dengan metode pengenalan wajah. Ketika gambar wajah cocok dengan yang ada dalam database maka user berhasil absen dan disimpan ke dalam database attendance.

\section{Requirement}

Dalam perancangan aplikasi absensi pada penelitian ini dibutuhkan beberapa tools agar aplikasi selesai dan berjalan sesuai dengan yang diharapkan. Tools yang di gunakan dapat dilihat pada tabel 1 .

TABEL I

REQUIREMENT

\begin{tabular}{|c|c|c|c|}
\hline No. & Item & $\begin{array}{c}\text { Requirement } \\
\text { Developer }\end{array}$ & $\begin{array}{c}\text { Requiremen } \\
\text { t User }\end{array}$ \\
\hline 1 & PC & Yes & Yes \\
\hline 2 & Webcam & Yes & Yes \\
\hline 3 & Operating System & Yes & Yes \\
\hline 4 & Web Server & Yes & No \\
\hline 5 & Web Browser & Yes & Yes \\
\hline 6 & Code Editor & Yes & No \\
\hline
\end{tabular}

\section{Hasil Dan Pembahasan}

\section{A Halaman Admin}

Ketika user berhasil login sebagai Admin maka user akan di direct ke halaman admin. Fungsi utama halaman admin pada penelitian ini adalah pengambilan data wajah karyawan kemudian mentrainingnya dan beberapa fitur lain seperti tambah dan edit data karyawan. Sub menu halaman admin dapat di lihat dilihat pada gambar 4. 


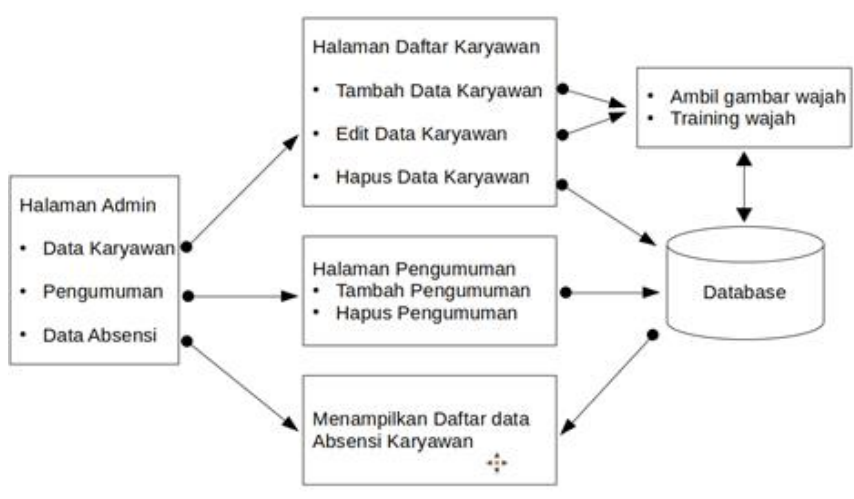

Gambar 4. Sub menu halaman admin.

Halaman data karyawan merupakan salah satu sub halaman dari halaman utama admin. Fungsi halaman ini adalah melihat daftar karyawan yang telah terdaftar oleh admin dapat dilihat pada gambar 5 .

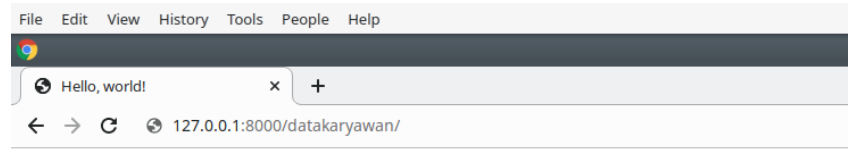

\section{Daftar Karyawan}

\begin{tabular}{l}
\multicolumn{2}{|l|}{ masukan keyword } & Cari \\
\begin{tabular}{|l|l|l|l|l|l|}
\hline No. & Nik & Nama & No. Telpon & Jabatan & Aksi \\
\hline 1 & 4738242 & Arwan & 088723628 & Leader & Edit | Hapus \\
\hline 2 & 352736 & Satria Puta & 0873463980 & Manager & Edit | Hapus \\
\hline 3 & 7233236 & Sopian & 0880137733 & Supervisor & Edit | Hapus \\
\hline
\end{tabular} \\
Tambahkan data karyawan \\
Kembarli ke Beranda
\end{tabular}

Gambar 5. Halaman Daftar Karyaawan

Tambah data karyawan berfungsi untuk menambahkan data karyawan dan data wajah baru. Halaman tambah data karyawan bisa dilihat pada gambar 6 .

File Edit View History Tools People Help

9

6 Menambah Data Karyawan $x+$

$\leftarrow \rightarrow$ C (5) 127.0.0.1:8000/tambah/

\section{Tambah Data Karyawan}

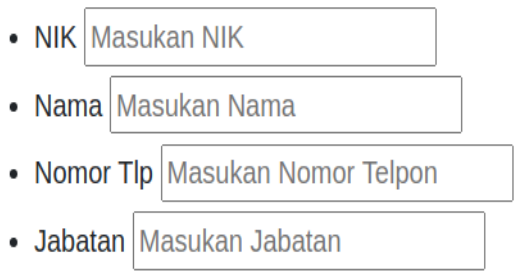

Gambar 4. Halaman tambah data Karyawan.

Fitur Tambah foto karyawan merupakan suatu tahap pengambilan foto karyawan yang dilakukan oleh user admin.
Fitur ini terdapat pada 2 halaman yaitu halaman tambah data karyawan ketika admin menginputkan karyawan baru dan terdapat juga pada halaman edit data karyawan dengan data karyawan yang sudah diinputkan tetapi belum dilakukan pengambilan foto.

Koneksi halaman web untuk membuka webcam dikirim dengan menggunakan fungsi href pada HTML.

<a href="/detect" $>$ Tambah Foto Karyawan</a>

Setelah dikirim perintah dikirim melalui href kemudian akan ditangkap oleh urlpatterns yang terdapat pada terdapa file urls.py. File urls.py merupakan file yang berfungsi untuk mengolah semua url yang ada pada web framework django.

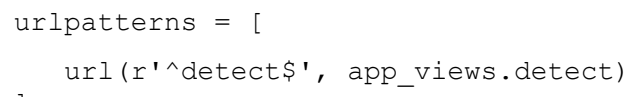

Pada kode program diatas di tunjukan bahwa destinasi selanjutnya adalah "app_views.detect" yang artinya memanggil fungsi detect yang terdapat pada file views.py pada aplikasi. Fungsi yang digunakan untuk membuka webcam sebagai berikut.

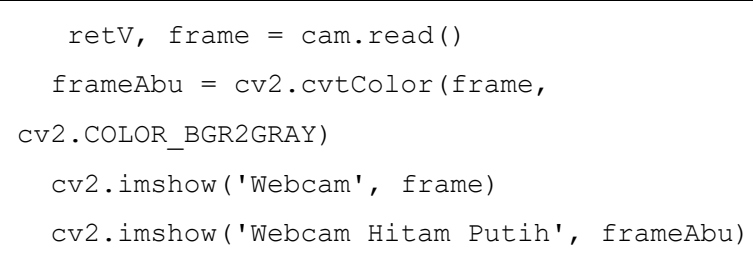

Ketika tombol tambah foto ditekan dua jendela kamera akan muncul. Jendela pertama dengan tampilan berwarna yang berfungsi sebagai preview dan jendela kedua dengan tampilan yang sudah dikonversi kedalam grayscale atau hitam putih yang berfungsi untuk mengurangi kedalaman warna [11]. Tombol ambil gambar dengan menekan tombol $c$ kemduidan file yang disimpan akan adalah hasil gambar yang berwarna. Proses konversi ke grayscale akan dilakukan oleh program ketika program training dijalankan. Langkah pengambilan gambar wajah dapat di lihat pada gambar 7 .

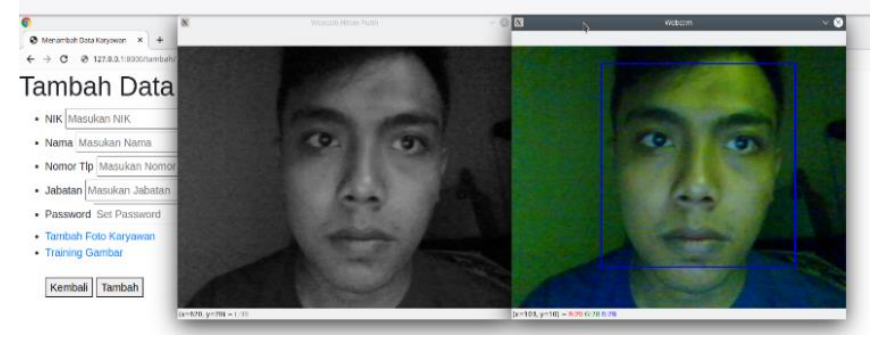

Gambar 7. Poses pengambilan gambar wajah.

Langkah selanjutnya adalah proses training data wajah yang telah diambil sebelumnya. Berikut kode program pengambilan data wajah. 


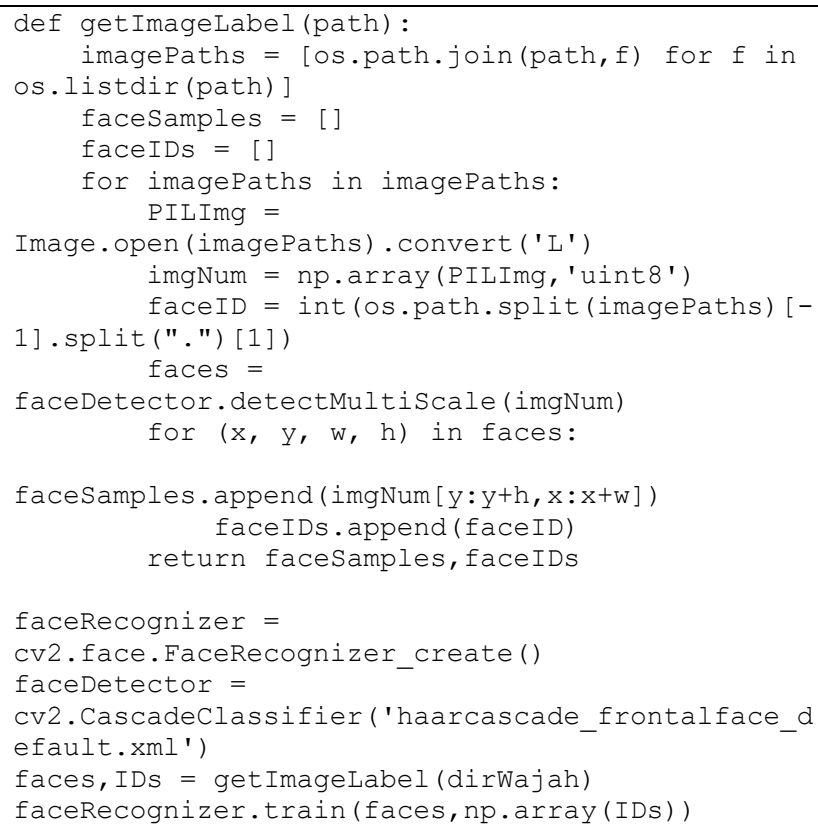

Pada test pertama pegambilan gambar wajah sebanyak sepuluh kali dengan jarak $\pm 50 \mathrm{~cm}$ dari kamera. Gambar kemudian disimpan sebagai persiapan proses training. Hasil pengambilan gambar dapat dilihat pada gambar 8 .

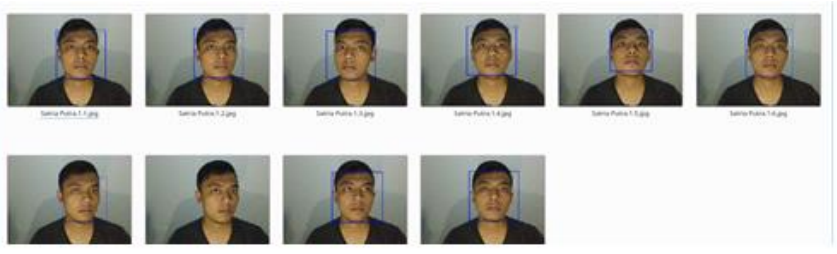

Gambar 8. Pengambilan gambar untuk test peratama.

Berikut adalah kode program dari pengenlana wajah

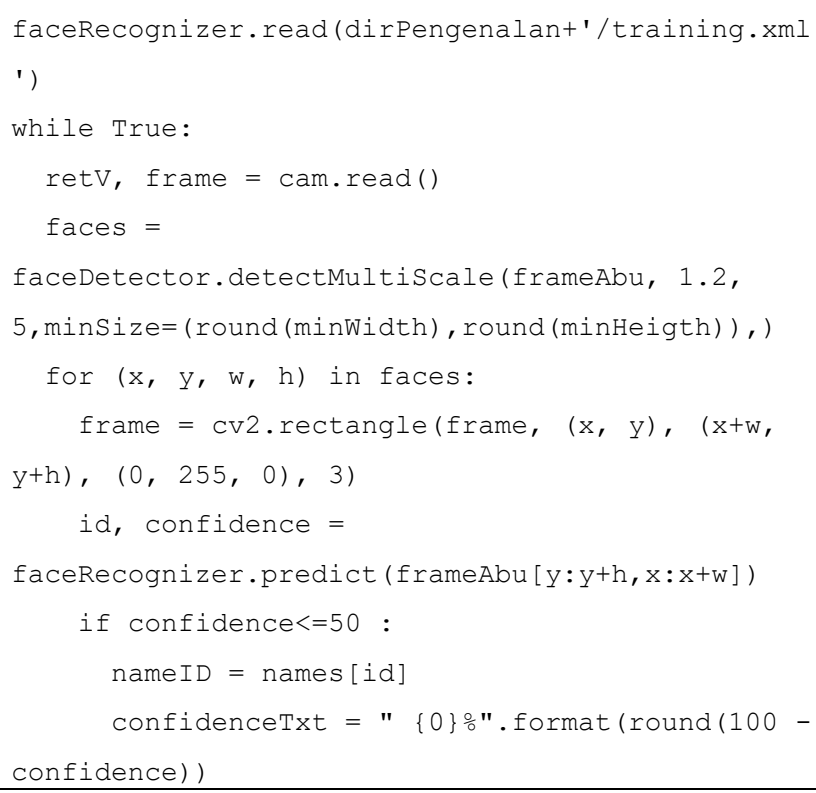

cv2.imshow('FaceRecognition', frame)

Hasil yang didapatkan pada training pertama didapatkan nilai akurasi pengenalan stabil pada angka $83 \%$ dapat dilihat pada gambar 9 .

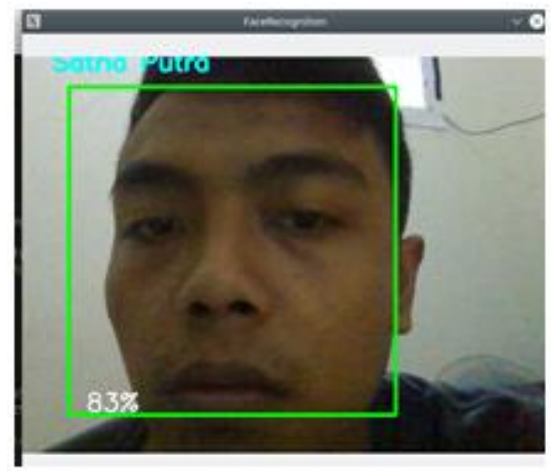

Gambar 9. Hasil test peratama.

Pada test kedua dilakukan pengambilan gambar wajah dengan jarak yang kurang lebih sama dengan test pertama kondisi yang baik. Hasil pengambilan data ke dua dapat dilihat pada gambar 10 .

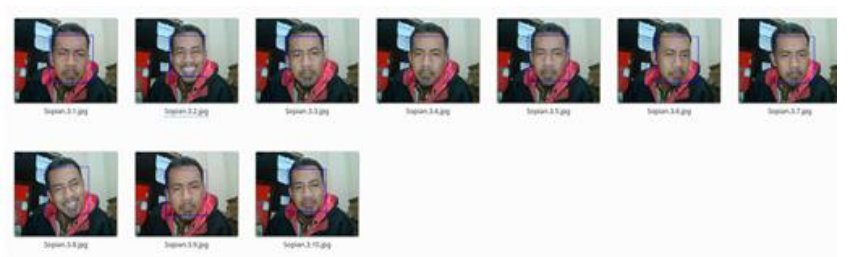

Gambar 10. Pengambilan gambar test ke dua.

Dalam test ke dua dalam jarak yang sama yaitu $\pm 50 \mathrm{~cm}$ di dapatkan nilai akurasi pengenalan wajah stabil pada angka $65 \%$. hasil test ke dua dapat di lihat pada gambar 11 .

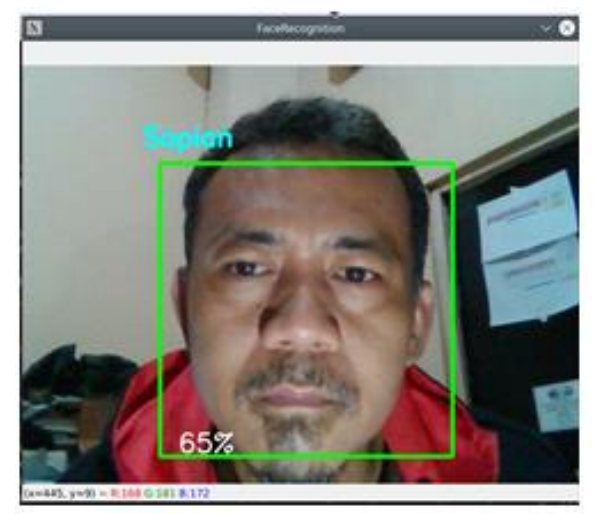

Gambar 11. Hasil test ke dua.

Percobaan ke tiga mengambil gambar wajah dengan jarak \pm 50 dengan pencahayaan yang sedang. Hasil pengmabilan gambar wajah dapat dilihat pada gambar 12 . 


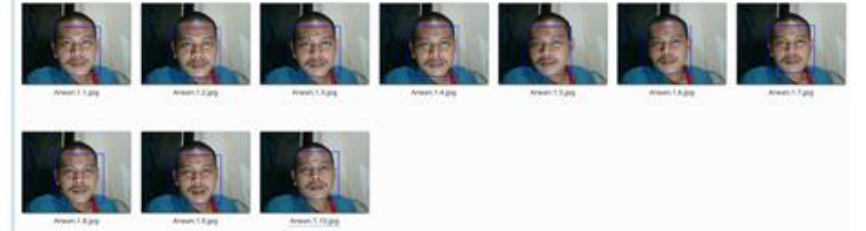

Gambar 12. Pengambilan gambar untuk test ke tiga.

Hasil akurasi gambar pada test ke tiga mendapat nilai dengan nilai $65 \%$. hasil test akurasi ke tiga dapa dilihat pada gambar 13.

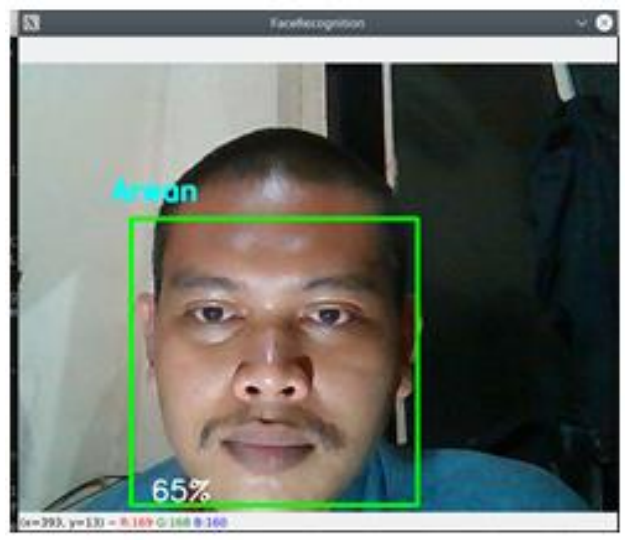

Gambar 13. Hasil test ke tiga.

Dari hasil uji coba yang di lakukan beberapa kali test dapat dengan jarak dan pencahayaanyang berbeda maka di dapat hasil yang berbeda. Hasil pengujian dapat dilihat dalam bentuk tabel 1 .

TABEL II

PRESENTASE AKURASI

\begin{tabular}{|c|c|c|c|c|}
\hline No. & Nama & $\begin{array}{c}\text { Jarak } \\
(\mathbf{c m})\end{array}$ & Cahaya & $\begin{array}{c}\text { Presentase } \\
\text { akurasi (\%) }\end{array}$ \\
\hline 1 & Satria & \pm 50 & Sedang & $77-87$ \\
\hline 2 & Sopian & \pm 50 & Bagus & $60-68$ \\
\hline 3 & Arwan & \pm 50 & Sedang & $60-70$ \\
\hline
\end{tabular}

Fitur selanjutnya adalah Pengumuman yaitu fitur admin yang dapat memberikan sebuah pengumuman baru atau menghapus pengumuman lama yang kemudian akan ditampilkan kedalam halaman utama client. Halaman pengumuman dapat dilihat pada gambar 14.

\section{Pengumuman}

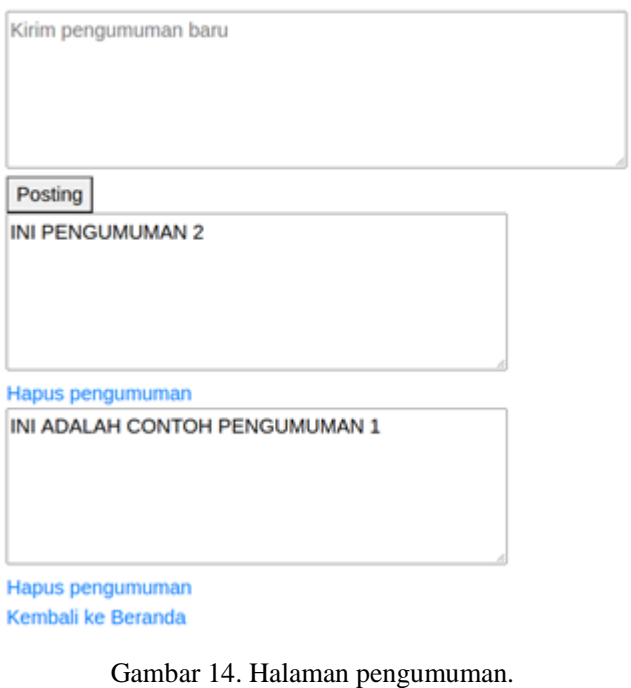

Data Absensi merupakan sebuah halaman yang menampikan daftar karyawan yang telah melakukan absensi. Tampilan halaman dapat dilihat pada gambar 15 .

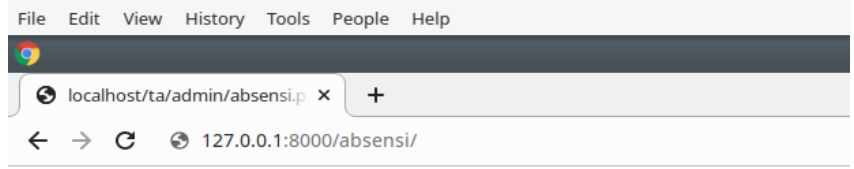

\section{Daftar Absensi Karyawan}

\begin{tabular}{|l|c|l|l|}
\hline No. & \multicolumn{1}{|c|}{ Nik } & \multicolumn{1}{|c|}{ Nama } & Lihat \\
\hline 1 & 4738242 & Arwan & Data absensi \\
\hline 2 & 352736 & Satria Puta & Data absensi \\
\hline 3 & 7233236 & Sopian & Data absensi \\
\hline
\end{tabular}

\section{Gambar 15. Halaman data absensi.}

\section{B Halaman Client}

Halaman utama client memiliki tiga fitur utama diantaranya, absensi masuk/keluar, lihat daftar hadir dan menampilkan pengumuman yang dikirimkan oleh admin. Halaman utama client dapat dilihat pada gambar 16. 


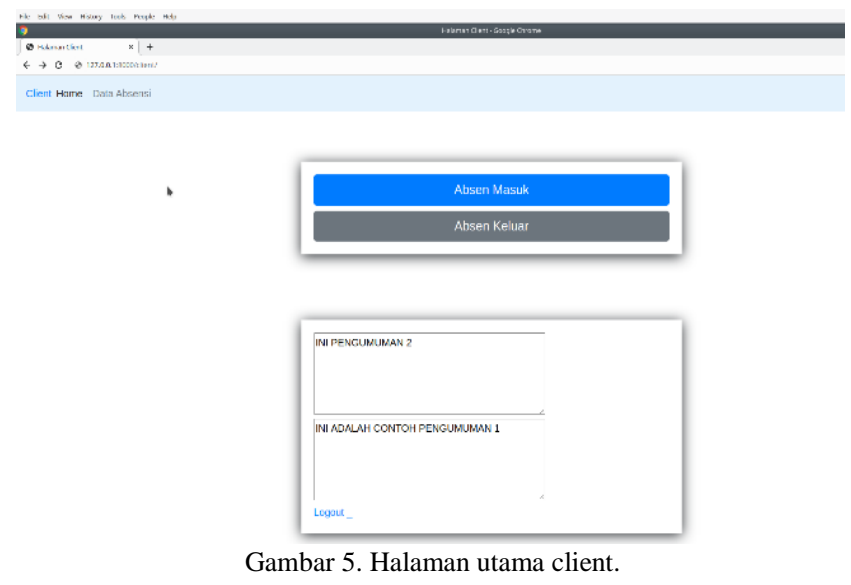

User client ketika tombol absen masuk/keluar ditekan maka akan muncul jendela webcam sebagai autentikasi absensi. Jika nama yang user client yang sedang dalam keadaan login sama dengan wajah yang terdeteksi dengan minimal nilai akurasi sebesar $60 \%$ maka absensi masuk atau keluar berhasi dilakukan. Proses absensi dapat dilihat pada gambar 17.

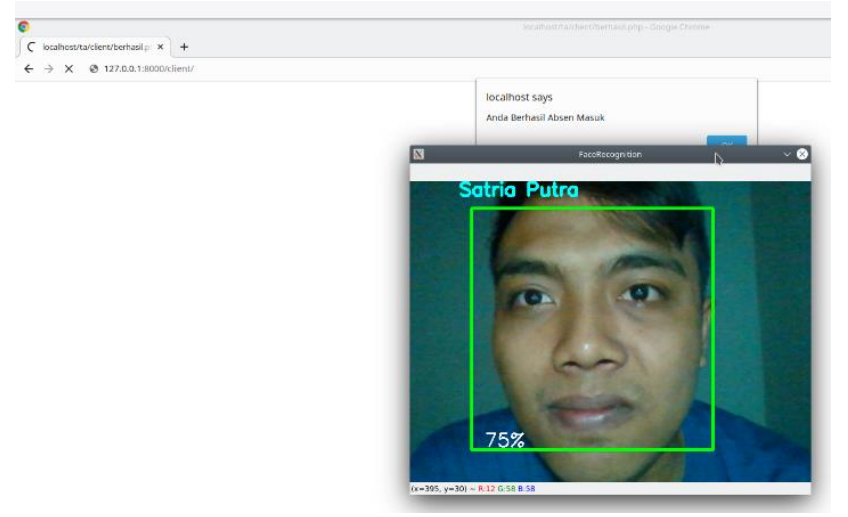

Gambar 17. Proses absensi user client.

Ketika user client sudah berhasil melakukan absensi dengan metode pengenalan wajah maka data akan disimpan ke dalam database berupa data tanggal dan jam pada saat melakukan absensi. Hasil dari absensi dapat dilihat pada gambar 18 .

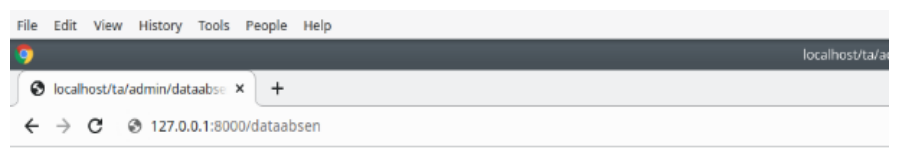

\section{Data Absensi Satria Putra}

\begin{tabular}{|l|l|l|}
\hline Tanggal & Masuk & Keluar \\
\hline $12 / 12 / 20$ & 08.55 & 09.11 \\
\hline $13 / 12 / 20$ & 09.07 & 09.12 \\
\hline $14 / 12 / 20$ & 13.22 & 13.31 \\
\hline \multicolumn{3}{|c|}{ Kembarli ke Beranda }
\end{tabular}

Gambar 18. Daftar hadir setelah melakukan absensi.

\section{KESIMPULAN}

Pada penelitian perancangan aplikasi absensi menggunakan metode eigenface yang terdapat didalam library OpenCV yang merupakan library opensource. Dapat ditarik kesimpulan bahwa tingkat pencahayaan dan jarak antara kamera dengan obejek pada pengambilan gambar wajah dapat mempengaruhi kualitas gambar dan hasil training. Pada uji coba yang dilakukan dengan dua jarak yang berbeda. Jarak terdekat memberikan hasil yang lebih akurat dibandingkan jarak yang lebih jauh. Ketika jarak wajah dengan kamera semakin dekat maka struktur dari bentuk wajah akan semakin jelas dan memberikan ciri karakteristik dari wajah orang tertentu. Peran pencahayaan juga memperjelas bentuk atau struktur dari wajah seseorang. Penggabungan antara jarak dan pencahayaan yang ideal akan memberikan hasil yang lebih akurat.

\section{DAFTAR PUSTAKA}

[1] M. R. Muliawan, B. Irawan, and Y. Brianorman, "Implementasi Pengenalan Wajah DenganMetode Eigenface Pada Sistem Absensi," Jurnal Coding, Sistem Komputer Untan, vol. 03, no. 1, pp. 41-50, 2015.

[2] I. Abdussalam, A. Rizal, and S. Aulia, "Desain dan realisasi sistem pendeteksi wajah untuk absensi karyawan dengan metode 2 d-det dan pca menggunakan webcam," 2012.

[3] M. W. Septyanto, H. Sofyan, H. Jayadianti, O. S. Simanjuntak, and D. B. Prasetyo, "Aplikasi Presensi Pengenalan Wajah Dengan Menggunakan Algoritma Haar Cascade Classifier," Telematika: Jurnal Informatika dan Teknologi Informasi, vol. 16, no. 2, pp. 87-96, 2020 .

[4] M. Arsal, B. Agus Wardijono, and D. Anggraini, "Face Recognition Untuk Akses Pegawai Bank Menggunakan Deep Learning Dengan Metode CNN," J. Teknol. dan Sist. Inf., vol. 6, no. 1, pp. 55-63, 2020.

[5] M. W. Septyanto, H. Sofyan, H. Jayadianti, O. S. Simanjuntak, and D. B. Prasetyo, "Aplikasi Presensi Pengenalan Wajah Dengan Menggunakan Algoritma Haar Cascade Classifier," Telematika: Jurnal Informatika dan Teknologi Informasi, vol. 16, no. 2, pp. 87-96, 2020.

[6] D. E. Kurniawan, K. Adi, and A. F. Rohim, "Sistem Identifikasi Biometrika Wajah Menggunakan Metode Gabor KPCA dan Mahalanobis Distance,” J. SIST. INF. BISNIS, vol. 2, no. 1, 2014.

[7] D. I. Bramantio, "Perancangan Dan Implementasi Keamanan Pintu Berbasis Pengenalan Wajah Dengan Metode Eigenface," tektrika, vol. 1 , no. 2, 2019

[8] N. W. Marti, "Pemanfaatan gui dalam pengembangan perangkat lunak Pengenalan citra wajah manusia menggunakan metode Eigenfaces," 2010 .

[9] S. Salamun and F. Wazir, "Rancang Bangun Sistem Pengenalan Wajah Dengan Metode Principal Component Analysis," rabit, vol. 1, no. 2 , pp. 59-75, 2016

[10] S. Subiantoro and S. Sardiarinto, "Perancangan Sistem Absensi Pegawai Berbasis Web Studi Kasus: Kantor Kecamatan Purwodadi," Swabumi, vol. 6, no. 2, 2018

[11] D. Suprianto and R. N. Hasanah, "Sistem Pengenalan Wajah Secara Real-Time dengan Adaboost, Eigenface PCA \& MySQL," Jurnal Eeccis, vol. 7, no. 2, pp. 179-184, 2014.

[12] S. R. Wurdianarto, S. Novianto, and U. Rosyidah, "Perbandingan euclidean distance dengan canberra distance pada face recognition," Techno. Com, vol. 13, no. 1, pp. 31-37, 2014.

[13] D. E. Kurniawan, and A. Dzikri, "Pengenalan Personal Berdasarkan Pengukuran Jarak Citra Wajah Menggunakan Pendekatan Linear dan Nonlinear," SNTIK 2015 